\title{
VORBEMERKUNG ZU TEXT UND KRITISCHEM APPARAT
}

Im Juli 2015 ist Prof. Dr. Martin West, Unterstützer und Experte unseres Projekts in textlichen Fragen von Beginn an, unerwartet aus dem Leben gerissen worden. Wir verneigen uns vor seiner Lebensleistung und werden ihn und seine engagierte Mitarbeit an unserem Kommentar stets in dankbarer Erinnerung bewahren.

Frau Dr. Almut Fries (Oxford) danken wir herzlich für die kurzfristige Erstellung des gekürzten, auf den Prinzipien von Martin West basierenden textkritischen Apparats. 
